\title{
Funeral for a Homeless Vagrant? Religious and Social Margins
}

\author{
Lucy Bregman
}

Citation: Bregman, Lucy. 2021. Funeral for a Homeless Vagrant? Religious and Social Margins. Religions 12: 30. https://doi.org/ $10.3390 /$ rel12010030

Received: 2 November 2020 Accepted: 30 December 2020 Published: 1 January 2021

Publisher's Note: MDPI stays neutral with regard to jurisdictional clai$\mathrm{ms}$ in published maps and institutional affiliations.

Copyright: () 2021 by the author. Licensee MDPI, Basel, Switzerland. This article is an open access article distributed under the terms and conditions of the Creative Commons Attribution (CC BY) license (https:// creativecommons.org/licenses/by/ $4.0 /)$.
Department of Religion, Temple University, Philadelphia, PA 19122, USA; bregman@temple.edu

\begin{abstract}
A "homeless vagrant" was the term used by Protestant clergy of the first half of the twentieth century for a man without name, family or history who died on the street. Clergy were asked to perform a funeral for him, but as his religious status was unknown, his funeral posed a problem for them. How could one preach a hopeful Christian message, for one who may not have had faith in Christ? This paper uses pastors' manuals and sermon collections to understand how this kind of "problem funeral" was interpreted as an example of a marginal death both religiously and socially. Although there were no mourners, the purpose of the funeral was worship of God, who was always ready to receive us. The homeless vagrant's funeral was also an occasion for reproach, against the anonymity, impersonality and moral danger of urban life. The homeless vagrant's extreme isolation and abandonment made him a warning to all. The paper closes with the contrast between this view of death on the street, and that conveyed in recent Homeless Persons Memorial Day services, organized by activists for the homeless. The latter see the homeless as persons with names and stories, part of a counter-community in cities. The tone of reproach is much more prominent here, too. Society has failed these people.
\end{abstract}

Keywords: funeral; homeless; death

\section{A Homeless Vagrant's Funeral as a Religious Problem}

Early in the twentieth century and undoubtedly before that a sad scene would take place. A man was found dead on the street of an American city, with no personal identification, nor a way to contact any family members. He had certainly been a "homeless vagrant," someone who lived on the street. The term itself was derogatory, as "vagrancy" was a criminal offense. One could assume the wretched man was penniless, filthy and alone when he died. No medical diagnosis for his death seemed relevant, although exposure and starvation would have been likely. There were no modern biological tests for identification, and even if there had been, no one in authority would have thought it worth paying for them. The only job was to hold the body for a while in the city morgue, then bury the poor man in a municipal graveyard. However, at the burial, a clergyman was called in, to preside at a funeral. Somehow, the city authorities thought it necessary to have a religious functionary present, to do something right before the burial. Was this even a funeral, with no mourners, and the only congregation the gravediggers? What were the problems posed by this melancholy situation? How were these problems defined, against what norms of how a death should be ritually marked? And why should we, now, care about this lonely and miserable situation?

The answer to this last question fits within the theme of this issue, "Death in the Margins." To look at how such a socially marginal death was viewed as a religious issue in the past can shed light on both how marginal lives are identified and given symbolic status, and also on how religious resources were used to both draw margins and overcome them. Behind the topic now, and in the past, there lurks the suspicion that "margins" themselves are somehow wrong, a sign of society's failure, a failure religion can only partially mitigate. Not only should there be no "homeless vagrants," but the very idea of placing anyone outside the social order is itself an evil. Although the definition of the situation and its 
protagonists has certainly changed since the early part of the last century, the issue of marginal death remains a bitter reminder of how far we have not come.

This study of the homeless vagrant's funeral is drawn from sermon anthologies and handbooks written by and for pastors from the first half of the last century. These were also published in the United States, and assume flourishing religious communities at ease with government, although never directly sponsored by it. Pastors used such books to prepare their own funeral sermons and develop skills to cope with special problem situations. This was before many denominations issued standard worship books, so that there was more freedom to design the funeral program, or include materials such as poetry in the midst of the service. That, however, put more of a burden on the novice pastor, who often felt insecure when asked to preside at a funeral. In the hundreds of sermons anthologized, and in all the advice contained in the manuals, there are no situations of dire or direct conflict between pastors and government officials or regulations (Bregman 2011, pp. 17ff.). Yet these documents do reveal problems and tensions, both theological and social. Additionally, of course, a funeral was the one occasion when the topic of death could not be avoided. Pastors knew that it was their duty to preach on death, to remind all those present at a normal funeral of the Christian message of death and eternal life.

The pastor's perspective captures only one stance or outlook. I do not pretend to look at this situation of the homeless vagrant's funeral from alternative viewpoints of that era, such as municipal documents or medical reports. It is a study of the religious issues as defined by a specific group with a particular agenda. In pastors' manuals and in anthologies of funeral sermons from that era, lasting until the mid-twentieth century, this situation of the homeless vagrant shows up as one of several "problem funerals." Alongside funerals for suicides, and for "fallen women," these were challenges for religious leaders at the theological level as well as in the challenge of sociological respectability. We may say that the case of the homeless vagrant was an instance of death at the margins of faith, as well as at the margins of the state. Since the source for these discussions is from pastoral resources, it represents only one perspective on the scene of the homeless, nameless deceased. We will close with a current radically different take on this urban situation.

It is first of all important to insist that, for clergy, funerals were always occasions for worship. Andrew Blackwood, Earl Daniels, and many others who wrote manuals for clergy on how to plan and conduct funerals, all agreed on this (Blackwood 1942; Conwell 1912; Daniels 1937; Hallock 1926; Ketcham 1899; Neumann 1912; Schuh 1925; Wallis 1953). Worship of God meant that "doctrinal sermons" were far preferable than those "biographical" ones that focused on the individual deceased's achievements. (Daniels 1937, p. 70) This spiritual purpose outweighed any familial or communal claims, which were relativized. Funeral directors, a profession since the late nineteenth century for urban Americans, were to care for the body, while the pastor focused on the soul, the true essence of the person (Blackwood 1942, p. 76). However, most of all, pastors were to focus on God, and their task was to direct the hearts and minds of the congregation to God. In the stark words of one preacher:

How do the living know that they shall die?

The living know that by the appointment of God, that they shall die.

What improvement should we make of this important subject?

We should sit loose upon the world. (Ketcham 1899, p. 114)

This went beyond mere psychological comfort. God alone was the true source of consolation for mourners. Additionally, mourners qua mourners were, unlike today, not the primary identification for those at the funeral. For the clergy at least, those present were the future dead. Whatever message was preached, it aimed to remind them that God and our own deaths awaited all. So, for example, the sudden death of a businessman served as a reminder of this for the congregation. If the week before, the man had been busy in his office, "Today we bury him. So you too may die. Are you living under the 
power of the world to come?" (Ketcham 1899, p. 18) Not all funeral sermons were this stark, but they shared this sense of death's power to pull people's minds toward God, toward ultimate rather than earthly and temporary concerns. To provide what we would think of as psychological consolation was not their purpose. Christian funerals were filled with hope, but it was theocentric hope. With this message, too, human status and achievement became irrelevant-an important argument for why even a homeless vagrant should receive a funeral. However, of course, the problem then became, what if the dead vagrant had not been living under the power of the world to come?

Clergy saw themselves as the primary guides for what funerals were about, and who should be funeralized. In ordinary cases, funeral directors were active in caring for the physical body of the deceased, and yet the profession itself, being relatively new, was also treated in pastors' manuals as potentially suspect. The funeral director was sometimes eager to promote ostentatious and expensive funerals, which clergy denounced as "pagan," panderers to customers' desire for social status (Blackwood 1942, p. 76). The poor, those least able to afford fancy funerals, were the most vulnerable to this appeal, at least in the eyes of clergy. "Consumerist" complaints about the American funeral industry were already in place by early in the twentieth century. Yet there is very little evidence in any of the older sermons or manuals that the funeral director was the source of problems. "Problem funerals" never included conflicts with funeral directors, as it might have occurred that they were overcharging the norm. Cordiality between two professions appears to have been and to presently be the norm, right down to the recent collaboration of Tom Long and Thomas Lynch in The Good Funeral of 2013. As we will see, funeral directors were not players in the cases of homeless vagrants, where we have neither morticians, nor mourning family members as actors in the drama. Just the dead man, the gravediggers and the pastor.

Clergy from mainline Protestant denominations also saw themselves as civic leaders. Here, I may say, we are dealing with clergy from groups such as Episcopalians, Methodists, Presbyterians, Lutherans, Baptists-clergy known and respected in the city, or at least with a solid presence and reputation for accommodating requests from city agencies. I am not including Roman Catholic priests here, nor members of minority denominations associated with immigrant groups. Nor with non-middle-class denominations, such as Assembly of God. Mainline Protestant clergy, present at a variety of municipal functions, belonged as natural partners with civic authorities. In the words of Andrew Blackwood, "The Christian minister is the servant of his community, not merely of his parish." (Blackwood 1942, p. 183). Therefore, the same manuals provide instructions for presiding at funerals and memorials for civic leaders, or at Memorial Day commemorations. There were even sometimes instructions for presiding at military funerals (Blackwood 1942, p. 162). These were important public events, but for the clergy the primary aim of worship continued to hold sway. It is interesting how, in more recent pastors' manuals for conducting funerals, all mention of these occasions is dropped. While clergy may still be present, their ceremonial role may be minimized. Their focus is by now exclusively on the family, friends and work colleagues of the deceased. However, certainly through the 1950s, clergy from these mainline and mainstream branches of Christianity belonged at the center of the state, not at its margins, when it came to honoring and memorializing the dead.

\section{Sinful Lives, Isolation and Anonymity: Problem Funerals}

For these clergy, the most basic problem posed by the homeless vagrant's funeral was theological: the unknown status of the man (and it was always a man!) before God. Had he been a believer in Christ? Had he once had faith, and lost this along with his home and possessions? If nothing was known about him-not even his name-how could the preacher claim to assure anyone of the man's salvation? In the words of one pastor, "If this young man went before God's judgment throne with a living faith in Christ Jesus ... it is well with him. If he departed without this trusting faith, the Scriptures give us no word of comfort." (Schuh 1925, p. 213) In answer to this, the manuals' authors insist both on the 
omniscience and mercy of God. We do not presume to make judgments, but the default is hope that God will welcome this poor abandoned soul into his kingdom. Additionally, the normal message of the funeral is not primarily psychological consolation, even when there are plenty of mourners. It is to remind everyone that we too will make the transition from this life to the next. We are, in short, the future dead. This is just as applicable to the gravediggers and to the preacher himself as to a normal congregation filled with grieving family. Funerals are about our relationship to God, a universal purpose. Clergy were not to assume that because the deceased's human relationships had failed, God too had vanished.

It is obvious that most clergy detested what they considered "problem funerals." Contemporary manuals and sermon anthologies share this distaste, although their reasoning and identification of problems are different. No one likes a situation in which their honesty may be tested. "In a case where the minister can find no ground for Christian comfort, he is fortunate if he is not expected to speak" (Blackwood 1942, p. 136). This was especially true where those of the congregation knew perfectly well what kind of human being was funeralized. The homeless vagrant is actually in a better position according to this clergy stance, than that of the other frequently mentioned "problem funerals," due to his anonymity and the lack of mourners. The religious status of the "fallen woman" and the suicide posed greater problems, since what was definitely known of them was so detrimental. The "fallen woman" had violated social and religious norms, and presumably done so flagrantly and without clear signs of repentance (unlike in the opera "La Traviata," where the heroine is redeemed by love, and certain that God has forgiven her past sins). Clergy were warned against saying anything personal about the deceased in these cases; it would either be a lie, or an embarrassment to everyone. Here, the preference for "doctrinal" sermons helped, for these placed emphasis on the truths of salvation applicable to all.

Suicide, which defied God's will about the timing and manner of one's own death, was the most difficult case of all. In all the hundreds of anthologized funeral sermons from the first half of the last century, I found only two that preached for suicides (Neumann 1912, pp. 131-33; Schuh 1925, pp. 128-33). It was clear that even agreeing to do this was a choice that needed to be defended, as most pastors would have refused. Suicide, or "self-murder" was traditionally a sin from which there was no opportunity to repent, and therefore no possibility of salvation. It was not until later in the twentieth century, with the introduction of psychological perspectives on mental illness and depression, that this interpretation of suicide was replaced, at least for many clergy. The message of these two sermons was to ask for God's mercy, to warn against wasting one's life, and to urge those who could listen to accept the offer of salvation while it was still available (Neumann 1912, pp. 131-33). The unsaved status of the suicide was a mystery best left to God, but "Hereafter let us have greater fear of sin, and of that sin especially to which our brother has fallen victim." (Neumann 1912, p. 132). Once again, psychological consolation of the mourners was never the primary goal of the funeral, although perhaps even to hold a funeral at all offered a measure of consolation. While suicide funerals today are still excruciating, the focus is now on the emotional and social distress of the family, and allowance is made for the deceased person's mental instability and psychiatric illness. Thus, the religious issues here have been reframed, although suicide still heads the list of problem funerals in contemporary pastoral guides.

The homeless vagrant's anonymity could be viewed, ironically, as a protection, at least up to a point. No one really knew what kind of life or faith he had, and there was no community gathered to condemn him for his bad end. Yet, as one pastor commented, in regard to funeral services for "bootleggers and drunkards, suicides and harlots ... you are there thanking God that they were not willing to lay their dead away as if they had been burying a dead horse." (Daniels 1937, p. 209). The case of the homeless vagrant comes as close to that of a dead horse as one could imagine, and the treatment of the body must have shown the same lack of respect at times. However, there was, I think, another theological reason why performing a funeral for a homeless vagrant was so difficult. The funeral message conventionally draws on Biblical models and Biblical stories, in which faithful 
persons are shown facing death. Some of these may be problematic for other reasons, but the ideal might be the patriarchs who died surrounded by their sons, secure and ready to join their ancestors in hope of eventual resurrection (older understandings of the Hebrew Scriptures by Christians automatically assumed this was the case, although Biblical scholars might doubt that any firm hope for an afterlife was present at that early era). People in the Bible die as people normally did, surrounded by other people; it is a terrible thing to die absolutely alone. That is what makes the solitude of the homeless vagrant so unusual, and so unprecedented even as a religious situation. He threatened some certainty about human connectedness, as indeed he does for us whether or not we invoke Biblical ideals to express this. No one should die that alone, that nameless, that unremembered. The tragedy of today's COVID-19 victims in nursing homes is that they are forbidden good-bye visits from their family members. Yet they are, hopefully, still cared for, even if the staff are wrapped in personal protective gear. However, the homeless vagrant died without caregivers, at least in the image formed by pastors. Perhaps a victim of violence or alcohol (more recently, of drugs) this person's isolation and abandonment in death evokes a very basic human anxiety about our own ultimate aloneness. In a particularly tragic story, told by Blackwell, a man he describes as a drowned derelict died alone and no one came to claim the body. Only a few weeks later, an aged widow came and said, "This must have been my son's body" (Blackwood 1942, pp. 174-75). By then it was too late for any positive identification, and here bureaucratic inefficiency was to blame. The one human mourner who might have been there missed her opportunity, and the pastor who funeralized her derelict son was faced with deep regret and anxiety over human isolation.

Today, a pastor might look to the one most unhappy and emotionally isolated death in the Bible: that of Jesus on the cross. Deserted by most of his friends, mocked by the crowd and his fellow-convicts, his worst aloneness was the abandonment of Jesus by his Father. Perhaps for the first and only time in his life, he was truly and totally alone. Only in John's Gospel are there mourners at the foot of the cross (Mary and the Beloved Disciple, Jn 19:25-27), and in Mark and Matthew Jesus cries out in anguish at God's absence. ("My God, my God, why have your forsaken me?" are Jesus' last words in Mt 27:46 and Mk 15:34) This dying might have been a model for framing the case of the homeless vagrant, but it never was used or referred to in any of the sermons I have read. Jesus was portrayed as "homesick for Heaven," but never as the one who approached the homeless vagrant in his dying aloneness. Moreover, sermons of the early twentieth century were not Christocentric, they were not focused on Jesus' death and resurrection, as they later became under the influence of liturgical and theological influences. They were certainly theocentric, Godfocused, but not in such a way as to relate Jesus' own passion and death to our own, or to that of the homeless vagrant.

Pastors who did not deny the homeless vagrant a funeral did not want to judge that he was excluded from God's salvation. Nor was a more humanistic reason for holding a funeral invoked by them: that every human being, by virtue of being human, deserves a funeral and has a right to one, unlike a dead horse. This was voiced by Paul Irion, in an interesting 1966 book The Funeral: Vestige or Value? (Irion 1966, pp. 134, 189). By the time Irion wrote, funerals were already under attack, and the attitudes described so far appeared alien and irrelevant to many. Irion accepted that, by the 1960s, funerals had moved out of the umbrella of "worship." Family, funeral directors and civic authorities all had different ideas of their purposes. For Irion, funerals need not be a "vestige," they can be of "value." However, his argument is that everyone deserves some commemorative rite to say, "Someone was here." This is no longer worship. Earlier pastors could not have directly accommodated this rationale, although some may have privately accepted it. For them, a funeral performed well away from a church building, right by the municipal graveyard, is still an act of worship, not solely an act of service or charity for a fellow human being.

Before we dismiss this perspective as too restrictive or other-worldly, I want to insert a defense for the theocentric emphasis it assumed. God and God alone knows the identity of the homeless vagrant; no one is anonymous before God. It was important to remind those 
at the homeless man's funeral that what remained unknown to us was known by God. In contrast, and perhaps in keeping with "every human deserves a funeral," a method of dealing with a newer set of "homeless vagrants" was practiced recently by an Italian town where the bodies of drowned migrants washed up on the nearby shore. These were unidentified persons making an illegal crossing of the Mediterranean from North Africa. It was a fatal crossing. The Italian townspeople took responsibility for the burial of these alien dead in their local Catholic cemetery. To humanize them, they gave them all good Catholic Italian names on their markers. Yet it was all but certain that these dead had been Muslim in life. In death, however, a possible Muhammed became Mario, an Ahmed became Alberto-clearly with the best intentions. The locals who buried them wished to give them the dignity of reputable, familiar names (This story was told at the 2015 Centre for the Study of Death and Society Conference, Bath, UK).

The problem, however, from a theological viewpoint is that it ignored God's transcendent knowledge in favor of human power to name. It also usurped what could have been guessed about the dead persons' true identities and faith. One could argue that it was unfair to the dead to be posthumously baptized, even though becoming Italian residents was what they had hoped for as they boarded the doomed boats. However even more, it usurped or deleted God's presence to hold a human being in God's hands, to call him or her by name. To use the traditional language the clergy who performed homeless vagrants' funerals might have relied on, in the final judgment God will call on Muhammed and Ahmed, for better or worse. Mario and Alberto simply never existed. As Muslims in life, they would certainly not have been saved by Christ, but that too was up to God to decide. For many of the Protestant clergy 100 years ago, even the salvation of Roman Catholics (Mario and Alberto) would have been doubtful. However, no one remains anonymous before God. American homeless vagrants were the test case of this fundamental religious truth.

\section{Social Justice and the Message of Reproach}

Although this theological perspective remained dominant in the pastoral understanding of this situation, nevertheless, the funeral for a homeless vagrant is also an act that reproaches. However mute the tone, there is in this treatment of the homeless vagrant's plight a sense of injustice, of the failure of civic society to care for its own, and a failure of urban life to meet standards of fulfilling humanity. Urban life depersonalizes, making for anonymous existences not just for nameless vagrants. There is something threatening to all about urban environments, and the state is unable to overcome this. The municipal gravediggers present at the funeral are symbols of incomplete and failed care, even as they perform a necessary but ugly task. Behind this lies an ethos which appears much more directly in the other sermons of that era anthologized: the best environment, the most congenial to Christian faith, is rural or small town. Cities are risky and dangerous; you lose yourself and other people lose you when you end up in them.

To contrast with the dangerous chaos of cities, preachers endlessly evoked scenes of home back on the farm, and of pious mothers presiding over well-ordered, if frugal, households. These images are central to early twentieth-century Protestant sermons. They were tied to the cult of "domestic piety," where the harsh, masculine world of commerce and politics was contrasted with the gentle and pious and safe domain of the home (Bregman 2011, pp. 47ff.). Heaven was, of course, the ultimate Home, and these associations were used to build up that message. However, on earth, city life remained alien and dangerous. In one especially tragic tale of warning told by a pastor, he had performed a funeral for a nameless homeless vagrant, only to hear month's later from the dead man's mother. By a bureaucratic mistake, she had never been notified of her son's death, revealing both the failure of the state, and never-ending maternal love, the latter denied consolation by human sinfulness and urban indifference. While it was not literally the case that a move to an urban environment led to a disconnection from church or family, the risk was perceived as always there (In other national contexts, this risk was far 
greater. One cynical theory about nineteenth-century "secularization" in France was that the pavement stones of the Paris train stations invariably turned believers into atheists!).

Therefore, the homeless vagrant symbolized the man who had crossed into chaos from order, who had abandoned home, mother and a secure place in a structured community. Or, while God knows no margins nor boundaries, the nameless vagrant had stepped or fallen beyond the margins of all that we hold dear, of all bonds of human connectedness. While he had failed, society had also failed him. The state is what remains to pick up the pieces, but without offering love or belonging. The city gravediggers are not mourners, and the municipal cemetery is not the local churchyard or village resting place for the beloved dead.

\section{Disappearance of Homeless Vagrant Funerals as Pastoral Problems Today}

The problem of the homeless urban dead remains, as a sociological fact. However, it no longer appears in more recent pastoral guides to funerals the way it once did. Perhaps one reason is much better identification of dead bodies, and more ability and will to trace possible relatives. Efforts to do this are now far more organized, even when the outcome is to find remaining family members indifferent to the fate of their missing relatives. Another reason is the diminished reach of the mainline Protestant clergy. They are no longer so securely partners with civil authority, and when present in municipal formal rituals, they will share the stage with representative Roman Catholics, Jews and Muslims. Today, the problem situations addressed in pastoral manuals and sermon anthologies are all private: infighting among family members, for example, or the still-tragic situation of a suicide. These are treated as pastoral care for the mourners, with almost no attention to the eschatological destiny of the dead. Indeed, it is fair to say that all religious funerals in Protestant environments are Preaching to Mourners, the subtitle of a fine book "A Trumpet in Darkness: Preaching to Mourners" by Hughes (1985).

The exceptions to this privatization are police and firefighter funerals, which remain civic and religious occasions. They are not dealt with in books such as Hughes', because in large cities they have become so well-planned and managed large-scale events that special clergy are resource persons. In Philadelphia, alas, these funerals have become so frequent that their stage-managing has been perfected, a necessary step when other cities send numerous representatives of their own police and fire-fighters to join as mourners. A fine treatment of these events by Pamela Detrixhe revealed their blend of religion with cityoriented ritual ("To Protect and to Serve"). All Roman Catholic police funerals take place in the Cathedral of Sts. Peter and Paul. All funerals for non-Catholic, African-American police are held in a large African-American Baptist church. I would venture to say that the private faith of the deceased becomes almost irrelevant. Should a police officer who was Jewish, Muslim or Hindu die in the line of duty, it might even be permitted to funeralize them in the Cathedral.

The average Protestant pastor will not be dealing with these events. He, and now she, will remain local. They will have good relations with local funeral directors, will be invited to perform funerals even when the deceased was not a regular church member, and will become bereavement counselors to the family. Sometimes, clergy will be spokesperson to the media, on behalf of the family who are too traumatized by a death. However, the role of clergy in ongoing civic life and memorial occasions has become minimal compared to the past. They no longer need to be instructed in manuals about how to handle such responsibilities. Others will do the planning and orchestrate the ceremony.

\section{Contemporary Homeless Persons Memorial Day}

As the example from the Italian town's burials reminds us, there are new groups of homeless vagrants, in this country and elsewhere. Indeed, 10\% of the world's population now lives in a country other than the one they were born in. Many are undocumented, or illegal travelers, hoping to find new lives elsewhere. Many do not make it to land, or safely into their destinations. The disposal of their bodies is a complex question, and there 
are other essays in this issue that try to cover it. Not all communities are as welcoming or as willing to humanize the foreign dead as were those Italians. What distinguishes these newer groups of homeless dead is that they were headed somewhere definite, they had goals and hopes and plans. Were they illegals, refugees, a new diaspora? Many had relatives already living in the destination country, relatives left ignorant of why their siblings or cousins never arrived and could not be located. The plight of these families is what prompted some efforts to identify the bodies of those who crossed the Mexican border to die of exhaustion and thirst in Brooks County, a remote area of Texas. The "Yo Tengo Nombre" ("I Have a Name") project displayed website photos of the clothes and gear belonging to the migrant dead, in hope that these will provide identifications from families (since many of the families are living in the destination countries illegally, they are reluctant to step forward to authorities to submit DNA samples). While the term "homeless vagrant" might also be applied to these persons, I will stay with the older meaning, the current spiritual descendants of the men whose funerals were problematic in the past. Unlike would-be immigrants, they are headed nowhere, and so will never arrive anywhere.

The older urban homeless vagrant population became, once again, a visible feature of urban life in the 1970s and 1980s, when large traditional mental hospitals were closed. Their residents were supposed to be cared for in urban halfway houses and outpatient clinics, and eventually rejoin the community. Instead, they ended up without care, on the street. While since then there are other sources for today's homeless population, a large proportion are certainly mentally ill, alcoholics or drug addicts. There are homeless women, and homeless families, but the large majority of homeless persons are men. They live in marginal spaces, such as under the elevated section of I-95 in South Philadelphia. Or they gather along subway passageways (at one point, over 100 at the convergence of the two subway lines' underground passages), or alone by steam vents on city streets. Unlike the travelers who met their deaths going someplace with hope, these people have no destinations of their own. The city's destination for them is to move them at night into shelters. Project Home (n.d.), the advocacy and service organization for the homeless, sends its workers out in very cold weather (Code Blue) to persuade or cajole the street-dwellers to come to shelter indoors. Or, occasionally, to cajole police to let the homeless stay in the public area of a train station from which they are normally ousted at night (I am indebted to my one-time student, Russell Efferson (n.d.), for information about Project Home's ordinary operation).

Actually, some cities' destinations for the homeless are that they move elsewhere, anywhere but where they are. Philadelphia, where I live, is more realistic, and has tried to help some of them restore their lives. While the ultimate goal may be to provide low-cost safe housing for those who could manage it, it is clearly not a real possibility for all. In the meantime, a successful effort was to reach out to homeless veterans (the VA paired with Project Home for this) and at one point reduced the number of these to below 30. Although Project Home's motto is "No one is home until all are home," this cannot be achieved in today's urban environment. No one believes the homeless as a population will disappear; they are a permanent feature of contemporary urban life, and a permanent reproach to a society that has failed to care for all its members. In the COVID-19 pandemic, this failure became even more apparent, as this was one population intensely at risk for sickening and spreading the disease. In recent battles with the city over homeless encampments, they also appeared as especially vulnerable to political maneuvering.

However, as a religious issue or challenge, their status has changed. This, and not the many other social and economic and psychiatric dimensions of homelessness, is what I will continue to focus on. That religious concern is no longer most visibly focused on individual salvation, but on social ethics, is a failing society's responsibility. Just as important is a radically different portrait of homeless persons' identities from that held by clergy in earlier days. Evidence for this comes from a practice introduced in many American cities, Homeless Persons Memorial Day. Begun in 1988, it was officially recognized by the U.S. House of Representatives in 2010. Since its start by homeless advocates, the Memorial has been held about every two years, usually on 21 December, Winter Solstice. Its format 
includes speeches, processions, dinners and candle-lighting. Still, its most central activity is the naming of the past year's dead. In 2017, late in December, Project Home in Philadelphia held its Homeless Persons Memorial service for all those who died on the street during the past year. Homeless Persons Memorial Day offers a very different picture of what, to an outsider, appears to be the same population funeralized at the city graveyard without mourners. One difference is in the numbers of dead; the most recent total for one year in Philadelphia was 200, including both homeless and formerly homeless. While for the Protestant pastors a funeral for a homeless vagrant was a rare event, 200 makes street deaths common, almost two every three days. This extremely high number was due to the rise in drug overdoses from opioids, a major cause of death for these people, even before COVID-19 (by contrast, the figure back in 1998 for Atlanta was 600, spanning a ten-year period-and they thought this was huge).

However, the major difference is not the medical causes of death. It is that these persons are remembered by name - they are no longer anonymous. They are remembered as persons with stories, even if these are mostly unhappy. So, for example: "Marcus Foleti, an alcoholic who froze to death at age 58 in Wicker Park ... loved reading The Wall Street Journal" (Domonoske 2017). Each person is given a very brief biographical identification, so that they are no longer the anonymous figures of the earlier era's accounts. Additionally, as "the homeless," they are part of a community, a kind of at-the-margins neighborhood within the city. Even when one of them dies alone, they did not survive entirely alone. They had buddies, they had fellow-homeless persons who shared space with them, they did drugs or drank together (and sometimes murdered each other). Those who remember them may include family members, but the primary participants at the Homeless Persons Memorial Day are intended to be these fellow-homeless and ex-homeless persons, who recite their names or display signs as witnesses to the persons they memorialize. Very unlike the Italian situation, these are real names of real persons, or at least as close as anyone can come to recalling who the persons were and what they called themselves. Here, "Yo Tengo Nombre" rings true.

Ironically, the 2017 Philadelphia Homeless Persons Memorial Day commemoration did not take place at the margins of the state. The Mayor and other city officials were present, and it was held right outside the Municipal Services Building, across the street from City Hall! This is the most central location of Center City, the same place from which the controversial statue of Mayor Frank Rizzo has now been removed. What Rizzo would have thought of Homeless Persons Memorial Day, I do not want to guess, but most recently, not only current Mayor Jim Kenney, but agency representatives along with clergy and musicians were present, and, of course, the media. So, in this sense, it resembled those civic occasions in the past where religious leaders participated. By now, however, as with the musicians, they were participants in a program focused on other concerns, not directly on worship. Of course, as in any recent public event, the clergy were multireligious: a rabbi and an imam as well as a Protestant pastor were there.

The Homeless Persons Memorial Service is an occasion for mourning. However, the websites and publicity made it clear: their other purpose is reproach. The kind of homelessness and destitution that leads to street deaths should not be tolerated, and the state (represented by the City of Philadelphia) has appeased and accommodated rather than solved the problem. Although the individual city officials were commended for their support toward ending homelessness, there was no mistaking the tone of agonized and angry denunciation. The richest country in the world has learned to ignore or become resigned to the existence of homeless citizens. This reproach lacks any trace of reliance on a nostalgic ideal of peaceful smaller communities; urban life is taken as a given. However, it should not be as negligent and dangerous as it has become. Another paradox is that the local co-founder and executive director of Project Home is a nun, Sr. Mary Scullion, of the Sisters of Mercy-although the voices from Project Home do not invoke explicitly religious themes. Were they to do so, I suspect that the Biblical parallel they would find closest to their work would be that of the lepers in Jesus' time. Those were viewed as dangerous, 
defiling, and formed a counter-community at the edges of normal human places. Jesus took pity on them. However once again, the religious content and questions surrounding homeless vagrant funerals or memorials today is muted, and a ceremony at the plaza of the Municipal Services Building is not a ritual in the Cathedral of Sts. Peter and Paul.

\section{Conclusions}

As someone with a longterm interest in shifting ideas on death and religion in society, taking theological ideas and images seriously, I am not sure how the terms "margins" and "marginal" can be used here, except paradoxically. God has no margins. God's center is everywhere and God has no edges or boundaries: probably even the stodgiest and most conservative of those older clergymen would have accepted that. Their role was to witness that truth in situations where state and family had centers, boundaries and margins. The nameless individuals, who fell outside these borders, nevertheless belonged to God, and to those who could represent God at the crucial transition out of this life. They did this without expecting attention from anyone, let alone the heavy media presence that marks Homeless Persons Memorial Day. Yes, the minister should not hesitate to perform a funeral for a homeless vagrant. His role and its duties required this, however abnormal the circumstances may have been. He will become a witness to God's all-knowing transcendent presence and care when human care has failed. Additionally, as Christian funerals are filled with the hope and comfort that comes from God, a funeral with no mourners, for an anonymous dead man, is ultimately no different from any other funeral as an event of worship.

Funding: This research had no external funding.

Institutional Review Board Statement: Not applicable.

Informed Consent Statement: Not applicable.

Data Availability Statement: Not applicable.

Conflicts of Interest: The author declares no conflict of interest.

\section{References}

Blackwood, Andrew. 1942. The Funeral: A Sourcebook for Ministers. Phila: Westminster Press.

Bregman, Lucy. 2011. Preaching Death: The Transformation of Christian Funeral Sermons. Waco TX: Baylor University Press.

Conwell, Russell. 1912. One Thousand Thoughts for Funeral Occasions. New York: George H. Doran.

Daniels, Earl. 1937. The Funeral Message: Its Preparation and Significance. Nashville: Cokesbury Press.

Domonoske, Camila. 2017. Cities Across the U.S. Honor Homeless Persons' Memorial Day. Available online: https://www.npr.org/ sections / thetwo-way/2017/12/21/572744075/cities-across-the-u-s-honor-homeless-person-s-memorial-day?t=160946704395 0 (accessed on 31 December 2020).

Efferson, Russell, and Temple University, Phila, PA, USA. n.d. Personal communication.

Hallock, Rev. G. B. F. 1926. Cyclopedia of Funeral Sermons and Sketches. New York: George H. Doran.

Hughes, Richard. 1985. A Trumpet in Darkness: Preaching to Mourners. Philadelphia: Fortress.

Irion, Paul. 1966. The Funeral: Vestige or Value? Nashville: Abingdon.

Ketcham, William E., ed. 1899. Funeral Sermons and Outline Addresses: An Aid for Pastors. New York: Harper \& Brothers.

Neumann, R. 1912. Sowing in Tears, Reaping in Joy: A Collection of Funeral Sermons by Lutheran Pastors in America. Burlington: Germany Literary Board.

Project Home. n.d. Available online: www.projecthome.org (accessed on 31 December 2020).

Schuh, Rev. L. H., ed. 1925. Funeral Sermons. Columbus: The Book Concern.

Wallis, Charles L., ed. 1953. The Funeral Encyclopedia. New York: Harper \& Brothers. 